Celebes Education Review
http://journal.lldikti9.id/CER/index
Vol 2 No, 1 April 2020
p-ISSN: $\underline{\mathbf{2 6 5 6 - 7 3 8 5} \text { dan e-ISSN: 2684-7124 }}$

\title{
Peningkatan Kemampuan Motorik Halus Anak Melalui Kegiatan Menggambar pada TK Pelangi Kecamatan Gantarang Kabupaten Bulukumba
}

\author{
Intisari \\ 1 Pendidikan Anak Usia Dini, Universitas Muhammadiyah Makassar \\ Email: intisari@gmail.com
}

\section{Artikel info}

Artikel history:

Received; $12-3-2020$

Revised:25-03-2020

Accepted;28-03-2020
Abstract. The study was conducted to improve children's fine motor skills through drawing activities in the Pelangi Kindergarten, Gantarang District, Bulukumba Regency. This research is a classroom action (CAR) consisting of 4 steps (planning, implementation, observation, and reflection). This research was conducted in two cycles, cycle I was held 2 times and cycle II was held 2 times, the subject of this research was the kindergarten of Pelangi with 15 children and 1 teacher. Data collection is done through observation and documentation. The data analysis technique used is qualitative analysis which consists of: reducing data, presenting data and drawing conclusions. The results of the study show that in the first cycle of the first meeting the steps taken by the teacher in providing explanations are still unclear therefore observations on children cannot be carried out properly. At the second meeting the steps of the teacher have not been able to carry out activities properly, so that the observation of children is not carried out properly. In the second cycle of meeting I, the steps taken by the teacher were good so that the fine motor skills of children in drawing activities had increased but there were still students who could not carry out the activities properly. In the second cycle of Meeting II, the teacher has been able to carry out the steps of activities properly and correctly, so that observation on children in fine motor children has increased.

Abstrak. Penelitian dilakukan untuk meningkatan kemampuan motorik halus anak melalui kegiatan menggambar di Taman Kanak-kanak Pelangi Kecamatan Gantarang Kabupaten Bulukumba. Penelitian ini adalah tindakan kelas (PTK) yang terdiri atas 4 langkah (perencanaan, pelaksanaan, observasi, dan refleksi). penelitian ini dilaksanakan sebanyak dua siklus, siklus I dilakukan 2 kali pertemuan dan siklus ke II dilaksanakan 2 kali pertemuan, subyek penelitian ini adalah Taman Kanakkanak Pelangi yang berjumlah 15 anak dan 1 orang guru. 
Pengumpulan data lakukan melalui observasi dan dokumentasi. Teknis analisis data yang digunakan adalah analisis kualitatif yang terdiri dari: mereduksi data, penyajian data dan menarik kesimpulan. Hasil penelitian yakni pada siklus I pertemuan I langkah-langkah yang dilakukan guru dalam memberikan penjelasan masih belum jelas sehingga observasi pada anak belum dapat dilaksanakan dengan baik. Pada pertemuan II langkahlangkah guru belum dapat melakukan kegiatan dengan baik ,sehingga observasi anak tidak terlaksana dengan baik. Pada siklus II pertemuan I langkah-langkah yang dilakukan guru sudah baik sehingga kemampuan motorik halus anak dalam kegiatan menggambar sudah mengalami peningkatan namun masih ada anak didik belum bisa melaksanakan kegiatan dengan baik. Pada siklus II Pertemuan II, guru sudah mampu melaksanakan langkahlangkah kegiatan dengan baik dan benar, sehingga observasi pada anak dalam motorik halus anak sudah meningkat.

Keywords:

Motorik Halus;

Menggambar;

Taman Kanak-

Kanak.
Coresponden author:

Email: xxxx@gmail.com

artikel dengan akses terbuka dibawah lisensi CC BY -4.0

\section{PENDAHULUAN}

Usia dini dianggap sebagai usia keemasan karena pada usia tersebut, anak sedang mengalami perkembangan yang sangat baik secara fisik maupun psikis. Usia 6 tahun merupakan masa peka dalamperkembangan.Masa peka adalah masapematangan fungsi - fungsi fisik dan pikir yang siap merespon stimulasi lingkungan dan mengasimilasikan atau menginternolisasikan ke dalam pribadinya.Masaini merupakan masa awal pengembangan kemampuan fisik, kognitif, bahasa, sosial emosional, konsep diri, disiplin, kemandirian, seni, moral dan nilai-nilai agama.

Salah satu kemampuan anak yang sedang berkembang saat usia dini yaitu kemampuan motorik. Pada anak-anak tertentu, latihan tidak selalu dapat membantu memperbaiki kemampuan motoriknya. Sebab ada anak yang memiliki masalah pada susunansyarafnya sehingga menghambat keterampilan motorik tertentu. Ada beberapa penyebab yang mempengaruhi perkembangan motorik anak yaitu faktor genetik, kekurangan gizi, pengasuhan serta latar belakang budaya.Perkembangan motorik terbagi atas dua yaitu motorik kasar dan motorik halus.Motorik kasar memerlukan koordinasi kelompok otot-otot anak yang tertentu yang dapat membuat mereka melompat, memanjat, berlari, menaiki sepeda.Sedangkan motorik halus memerlukan koordinasi tangan dan mata seperti menggambar, menulis menggunting (Naim, 2005: 25).

Pada usia 5 atau 6 tahun koordinasi gerakan motorik halus berkembang pesat. Pada masa ini anak telah mampu mengkoordinasikan gerakan visual motorik, seperti mengkoordinasikan gerakan mata dengan tangan, lengan, dan tubuh secara bersamaan,antara lain dapat dilihat pada waktu anak menulis atau menggambar. Pada usia 5-6 tahun, banyak anak yang sudah sempurna 
motorik halusnya, karena bisa dilihat dalam kegiatan menggambar ataupun menulis. Dimana anak telah mampu mengkoordinasikan gerakan visual motorik, seperti menkoordinasikan gerakan mata dengan tangan, lengan dan tubuh secara bersamaan.

Motorikhalus adalah gerakan halus yang melibatkan bagian-bagian tertentu saja yang dilakukan oleh otot-otot kecil saja, karena tidak memerlukan tenaga. Namun begitu gerakan yang halus ini memerlukan koordinasi yang cermat.Semakin baiknya gerakan motorik halus membuat anak dapat berkreasi, seperti menggunting kertas dengan hasil guntingan yang lurus, menggambar gambar sederhana, menjahit, menganyam kertas serta menajamkan pensil dengan rautan pensil. Namun, tidak semua anak memiliki kematangan untuk menguasai kemampuan ini pada tahap yang sama.

Perkembangan Gerakan Motorik Halus anak taman kanak-kanak ditekankan pada koordinasi gerakan motorik halus dalam hal ini berkaitan dengan kegiatan meletakkan atau suatu objek dengan menggunakan jari tangan. Pada usia 4 tahun koordinasi gerakan motorik halus anak sangat berkembang bahkan hampir sempurna. Dalam hal ini seorang guru Taman Kanak-Kanak harus mampu menciptakan pembelajaran yang menyenangkan, menantang peserta didik untuk aktif, sehingga dapat memacu perkembangan fisik serta psikologis anak yang mampu mengembangkan kemampuan motorik halus anak.

Motorik halus anak adalah gerakan yang melibatkan bagian-bagian tubuh tertentu dan dilakukan oleh otot-otot kecil (halus) pada tangan dan jari yang terkordinasi dengan penglihatan.

Menurut Hamdani (2010: 42) menyatakan bahwa : "Motorik halus adalah aktivitas-aktivitas yang memerlukan pemakaian otot-otot kecil pada tangan. Aktifitas ini termasuk memegang benda kecil seperti manic- manic, butiran kalung, memegang sendok, memegang pensil dengan benar, menggunting, melipat kertas, mengikat tali sepatu. Aktivitas tersebut terlihat mudah namun memerlukan latihan dan bimbingan agar anak dapat melakukan secara baik dan benar".

Menurut Noorlaila (2010: 64) menyatakan bahwa "Motorik halus anak adalah gerakan anak yang menggunakan otot kecil atau hanya sebagian anggota tubuh tertentu. Perkembangan pada aspek ini dipengaruhi oleh kesempatan anak untuk belajar dan berlatih, kemampuan menulis, menggunting, dan menyusun balok.Kemampuan motorik halus adalah kemampuan seorang anak melakukan kegiatan yang berkaitan dengan pengendalian gerak dan memusatkan perhatian.Semakin muda anak, semakin lama waktu yang dibutukkan untuk berkonsentrasi pada kegiatan yang berkaitan dengan perkembangan motorik halus".

Sedangkan menurut Mudjito (2007:12) perkembangan motorik halus adalah "Kemampuan anak untuk mengamati sesuatu dan melakukan gerak melibatkan bagian-bagian tubuh tertentu dan otot-otot kecil , memerlukan koordinasi yang cermat serta tidak memerlukan banyak tenaga."

Perkembangan motorik halus yang dimaksud di sini adalahperkembangan otot-otot pada tangan si kecil untuk melakukan beberapagerakan yang membutuhkan koordinasi.Misalnya seperti memegangbenda-benda tertentu, menulis atau memegang sendok makannyasendiri. Melatih perkembangan motorik halus si buah hati sangatlahpenting karena gerakan motorik halus inilah yang nantinya akanmempermudah setiap aktivitas yang akan ia lakukan di sekolah. Jika iabelum bisa mengembangkan kemampuan motorik halusnya denganbaik, maka ia juga akan mengalami kesulitan untuk makan danmemakai pakaiannya sendiri. 
Papalia, et al (2012:17) Salah satu kunci untuk mengembangkankemampuan motorik halus anak adalah:"Dengan melatihnya untukmelakukan sesuatu secara rutin dan terus menerus sejak ia masih kecil.Anda bisa melatih kemampuan motorik halus anak dengan aktivitasmenggambar.Kegiatan seperti menggambar, menulis dan mewarnaisangat bagus untuk diberikan sesering mungkin kepada anak-anaksejak mereka duduk di bangku TK atau SD".

Aktivitas yang baik untuk melatih motorik halus anak-anak adalah menggambar dan menulis. Kalau ditanya mana aktivitas yang paling sulit, tentu semua akan menjawab menggambar. Hal ini dikarenakan saat menggambar, anak-anak harus menggunakan kemampuan mereka yang minimal dapat melibatkan 4 jenis kekuatannya yaitu kemampuan anak dalam menggunakan tubuhnya untuk mengekspresikan ide atau perasaannya(cerdas gerak), kemampuan berpikir yang dituangkan dalam gambar(cerdas gambar), pengetahuan mengenai diri sendiri dan kemampuanuntuk bertindak berdasarkan pengetahuannya tersebut (cerdas diri) dankemampuan untuk menyampaikan maksudnya melalui gambar (cerdasbahasa).

Aktivitas menggambar akan memberikan ruang untuk anakanakbisa mengekspresikan kecerdasan serta kreativitas yang merekamiliki sehingga mereka bisa bertumbuh menjadi anakanak yang lebihcerdas ketimbang ketika kita menyuruh mereka untuk belajar menghafaldan menghitung. Menggambar bisa membuat anak-anak lebihmengingat akan sesuatu hal karena dengan aktivitas ini ia diminta untukmenggambar sesuatu dan menceritakan apa yang sudah ia gambar,bukan hanya sekedar membaca dan menghafal apa yang sudah adasecara berulangulang. Adapun indikator dalam kemampuan otorik halus pada anak yaitu

\section{Koordinasi Mata dan tangan}

\section{Kelenturan otot jari tangan}

Aktivitas menggambar juga membutuhkan koordinasi antaramata dengan tangan.Ia akan belajar bagaimana menorehkan garissederhana yang lama kelamaan pasti akan berkembang menjaditorehan garis yang lebih kompleks dan jelas. Selain menggambar, andajuga bisa melatih gerakan motorik halus anak anda denganmengajaknya bermain menyusun balok, melipat dan merobek kertas,memasukkan benda ke dalam lubang, mewarnai serta membuat garis.Dengan cara ini, anda bisa melatih gerakan motorik halusnya sekaligusmengeksplorasi kreatifitas serta fungsi kerja otak si kecil.

Menggambar adalah kebiasaan pada anak usia dini yang merupakan kegiatan naluriah atau alami.Moeslichatoen (2004:41) mengemukakan bahwa " menggambar merupakan ekspresi segala sesuatu yang muncul dalam kesadaran pada saat itu yang diekspresikan bersifat simbolik dan bukan tiruan bendanya secara langsung"

Menggambar (drawing) adalah kegiatan manusia untukmengungkapkan apa yang dirasakan dan dialaminya baik mentalmaupun visual dalam bentuk garis dan warna. Menggambar adalahproses mengungkapkan ide, angan-angan, perasaan, pengalaman danyang dilihatnya dengan menggunakan jenis peralatan tertentu. Hasiltersebut disebut gambar (picture). Secara luas menggambar adalahkegiatan berkarya (membuat gambar) yang berwujud mata/duadimensi sebagai perwujudan tiruan yang menyerupai sesuatu (orang,binatang, tumbuhan, dan lainnya. Dalam arti sempit menggambaradalah kegiatan untuk mewujudkan angan-angan (pikiran, perasaan)berupa hasil goresan benda runcing (pensil, pena, krayon, kapur, dll)pada permukaan bidang datar (kertas, papan, dinding, dsb) yanghasilnya lebih 
mengutamakan tampil unsur garis.Menggambar dibuat dengan maksud untuk tujuan tertentuseperti menggambar rencana bangunan, menggambar peta,menggambar reklame, penuangan ide tidaklah sebebas seperti melukis.menggambar cenderung terkait masalah ketepatan bentuk, motif, polaukuran, proporsi kejelasan, kesan warna alamiah

Menggambar mempunyai pengertian suatu usaha mengungkapkan dan mengkomunikasikan pikiran, ide / gagasan, gejolak / perasaan maupun imajinasi dalam wujud dwimatra yang bernilai artistik dengan menggunakan garis dan warna. Dalam hal ini menggambar mengutamakan kegunaan sedangkan melukis mengutamakan ekspresi.Seni menggambar merupakan karya seni rupa yang paling mudah dan cepat untuk dihasilkan dengan goresan goresan yang berbekas pada suatu permukaan misalnya pensil untuk kertas atau benda - benda tajam untuk dinding gua pada masa lampau.

Menurut Sumanto (2006)menggambar merupakan suatu perbuatanseseorang dalam usahanya untuk mengungkapkan buah pikiran, sehinggabermakna visual pada suatu bidang dan hasilnya disebut gambar.Dalamkegiatan menggambar dapat dibedakan menjadi gambar dan lukisan.Lukisanmerupakan ungkapan buah pikiran yang disertai emosi yang mendalam,sedangkan gambar merupakan hasil buah pikiran saja.Jadi dapat dikatakanbahwa lukisan adalah gambar, namun gambar belum dapat dikatakanlukisan. Untuk dapat melukis, maka seseorang harus dapat menggambardengan baik dan memiliki keterampilan serta menguasai wawasan seni rupa.

Pembelajaran kegiatan menggambar di Taman kanak- kanak diarahkan dapat meningkatkan kemampuan motorik halus pada anak, agar anak memiliki persiapan yang matang sebelum bersekolah dan dapat menguasai gerakan- gerakan yang akan dilakukan pada saat bersekolah.

\section{METODE PENELITIAN}

Pendekatan yang digunakan adalah pendekatan kualitatif, yaitu suatu proses penelitian dan pemahaman yang berdasarkan pada metodologi yang menyelidiki suatu fenomena sosial dan masalah manusia. Penelitian ini termasuk penelitian tindakan kelas (Classroom Action Research) dengan menggunakan model prosedur PTK menurut Arikunto $(2010 ; 16)$ PTK yaitu penelitian yang dilakukan dalam bidang pendidikan yang dilaksanakan dalam kawasan kelas dengan tujuan untuk memperbaiki dan meningkatkan kualitas pembelajaran. Penelitian tindakan kelas dapat didefenisikan sebagai suatupenelitian tindakan (action reseach) yang dilkukan oleh guru yangsekaligus sebagai peneliti di kelasnya atau bersama-sama dengan oranglain (kolaborasi) dengan jalan merancang,melaksanakan, merefleksikantindakan secara kolaboratif dan partisifatif yang bertujuan untukmemperbaiki mutu proses pembelajaran di kelasnya melalui suatutindakan (treatment) tertentu dalam suatu siklus.

Dalam penelitian ini aspek yang di kembangkan adalah masalah dalampeningkatan kemampuan motorik halus anak melalui kegiatan menggambar di Taman Kanak- Kanak Pelangi Kecamatan Gantarang Kabupaten Bulukumba meliputi kemampuan anak dalam mencontoh bentuk, menirukan pola, dankelenturan jari. Salah satu cara mengatasinya dibuatlah perencanaan belajarmengajar yang baik. Untuk memecahkan masalah, peneliti membuatrencana baru yang mendorong pencapaian tujuan.

Indikator keberhasilan apabila 70\% anak didik telah berhasil mencapai kategori baik dalam hal peningkatan kemampuan motorik halus anak dalam kegiatan menggambar.

\section{HASIL DAN PEMBAHASAN}


Berdasarkan hasil penelitian pada siklus 1 dapat dijabarkan skenario sebagai berikut : Pada pertemuan pertama ini anak diajar untuk menggambar yaitu menggambar dari dasar bentuk titik garis hingga menjadi bentuk pelangi. Pada kegiatan awal guru dan anak didik melakukan kegiatan seperti salam,berdoa dan menyanyi. Setelah itu guru mengajak anak untuk bercakap cakap tentang kegiatan hari ini lalu guru mengadakan praktek berwudhu pada anak didik kemudian berdiskusi tentang kegiatan yang akan dilakukan pada hari ini yaitu menggambar dari dasar bentuk titik garis hingga membentuk pelangi. Langkah yang di tempuh guru yaitu memperkenalkan cara memegang pensil yang benar. Kegiatan inti yaitu guru meminta untuk menggambar dari dasar bentuk titik garis hingga membentuk pelangi

Kegiatan istirahat, guru membimbing dan mengingatkan anak untuk mencuci tangan sebelum dan sesudah makan, kemudian berdoa sebelum dan sesudah makan bersama- sama, dan setelah anak boleh bermain sesuai dengan keinginan anak tampa ada paksaan dari guru

Kegiatan penutup, guru mereviuew hasil kegiatan anak dan memberikan informasi kegiatan / permainan esok hari, sambil memberikatn penguatan nilai - nilai yang telah diajarkan. Terakhir guru mengajak anak - anak bernyanyi, berdoa dan pulang, serta bersalaman dengan guru.

Observasi di laksanakan selama proses kegiatan berlangsung berupa melihat persiapan guru dalam melakukan perencanaan dan pelaksanaan pembelajaran juga terhadap peningkatan kemampuan motorik halus pada anak melalui kegiatan menggambar hasilnya adalah menunjukkan bahwa dari 2 item bagi anak pada pembelajaran pertama dapat diuraikan sebagai berikut:

1) Pada langkah pertama, guru tidak mempersiapkan alat yang diperlukan oleh anak seperti alat gambar (pensil warna, krayo, spidol sehingga beberapa anak tidak mendapatkan alat gambar dan harus berebut dengan teman yang lain. Pada pelaksanaan ini guru mendapat kategori "Kurang".

2) Pada langkah kedua, guru mendapat kategori "Kurang" dikeranakan guru tidak memberikan penjelasan secara detai dan memperaktekkan cara menggunakan alat tulis tersebut sehingga anak hanya melaksanakan kegiatan tampa kordinator yang baik dari guru.

3) Pada tahap ketiga, guru memberikan perhatian kepada anak yang masih mengalami kesulitan dalam kegiatan menggambar namun hanya kepada beberapa anak didik saja sehingga guru memperoleh penilaian "Cukup".

4) Pada langkah ketiga guru memperoleh penilaian "Kurang dikarenakan guru tidak memberikan pujian dan memajang hasil karya anak didinding.

Pada indikator anak mampu dari dasar bentuk titik garis sehingga menghasilkan bentuk pelangi Pada kategori baik berjumlah 5 anak, 6 di kategorikan cukup dan 4 dikategorikan kurang. dari jumlah 15 anak didik yang diteliti jumlah keseluruhan $40 \%$ hasil observasi kemampuan menggambar anak berada dalam kategori cukup, 35\% dikategori baik dan $25 \%$ dikategorikan kurang.

Pada siklus II, Observasi di laksanakan selam proses kegiatan berlangsung berupa melihat persiapan guru dalam melakukan perencanaan dan pelaksanaan pembelajaran juga terhadap peningkatan kemampuan motorik halus pada anak melalui kegiatan menggambar hasilnya adalah menunjukkan bahwa dari 2 item bagi anak pada pembelajaran pertama dapat diuraikan sebagai berikut :

1) Pada langkah pertama, guru telah mempersiapkan alat yang diperlukan oleh anak seperti 
alat gambar ( pensil warna, krayo, spidol) sehingga beberapa anak sudah mendapatkan alat gambar tampn harus berebut dengan teman yang lain. Pada pelaksanaan ini guru mendapat kategori "Baik".

2) Pada langkah kedua, guru mendapat kategori "Baik " dikeranakan guru memberikan penjelasan secara detai dan memperaktekkan cara menggunakan alat tulis tersebut sehingga anak dapat melaksanakan kegiatan tampa kordinator yang baik dari guru.

3) Pada tahap ketiga, guru belum memperhatikan anak dengan seksama kepada anak yang masih mengalami kesulitan sehingga guru memperoleh penilaian "cukup"

4) Pada langkah keempat guru memperoleh penilaian "Cukup" dikarenakan memberikan pujian dan memajang hasil karya anak didinding.

Pada indikator anak mampu menggambar bebas menggunakan krayon sehingga menghasilkan sebuah gambar Pada kategori baik berjumlah 6 anak, 6 di kategorikan cukup dan 3 dikategorikan kurang. dari jumlah 15 anak didik yang diteliti jumlah keseluruhan $40 \%$ hasil observasi kemampuan menggambar anak berada dalam kategori cukup, 40\% dikategori baik dan $20 \%$ dikategorikan kurang.

\section{SIMPULAN DAN SARAN}

Berdasarkan hasil penelitian dan pembahasan di atas maka dapat di simpulkan bahwa pembelajaran dengan menggunakan kegiatan menggambar dapat meningkatkan kemampuan motorik halus pada anak di Taman Kanak - kanak Pelangi Kabupaten Bulukumba. Hal ini terlihat dari peningkatan kemampuan motorik halus anak setelah melakukan kegiatan penelitian dengan menggunakan kegiatan menggambar yaitu dari hasil penelitian yang dipaparkan pada bab sebelumnya, peneliti menemukan pada siklus I tidak semua anak mampu melasanakan semua jenis kegiatan dengan baik yaitu kemampuan anak hanya $40 \%$ dan kemudian dan kemudian setelah dilakukan beberapa perbaikan dalam melaksanakan kegiatan maka siklus II sebagian besar anak mampu melakukan dengan baik. Sehingga pada siklus II kemampuan anak meningkatkan yaitu $80 \%$ sehingga dapat meningkatkan kemampuan motorik halus anak.

Berdasarkan apa yang telah di sampaikan maka di sarankan agar dapat memberikat sumbangsi yang besar dan bersungguh - sungguh dengan mengembangkan kemampuan motorik halus anak di Taman Kanak - kanak karena kemampuan ini sangat di butuhkan dan menentukan keberhasilan mereka pada tahap perkembangan selanjutnya Kepada pihak sekolah disarankan agar dapat melengkapi sarana dan prasarana dalam upaya meningkatkan kemampuan motorik halus anak

\section{DAFTAR RUJUKAN}

Anggani Sudono. (2000). Sumber Belajar dan Alat Permainan (untuk Pendidikan Anak Usia Dini). Jakarta: PT.Grasindo.

Bambang Sujiono, dkk. (2007). Metode Pengembangan Fisik. Jakarta: UniversitasTerbuka

Direktorat Departemen Dasar dan Menengah Pembinaan Taman Kanak-kanak danSekolah.(2007). Pedoman Pembelajaran Bidang Pengembangan Seni diTaman Kanak-Kanak.Jakarta.

Endang Rini Suhanti. (2001). Diktat Perkembangan Motorik. Yogyakarta: FIKUniversitas Negeri Yogyakarta.

Hamdani, Agus. 2010. Melatih Motorik halus Anak Dengan Menggambar.(Online htpp/ www. Blogspot.arnet 66 com akses 29 September 2011)

Hildayani, Rini Dkk. 2007. Psikologi Perkembangan Anak. Jakarta: Universita Terbuka Hurlock, B Elizabeth. 2002. Perkembangan Anak Jilid I. Jakarta: Erlangga

Noorlaila, Iva. 2010.Kreatif Mendidik dan Bermain Bersama Anak. Yogyakarta Pinus. 
Mudjito. 2007. Model Pengembangan Keterampilan Motorik Anak Usia Dini.Jakarta : Departemen Pendidikan Nasional

Pamadhi Hajar. 2008. Seni Keterampilan Anak. Jakarta: Universitas terbuka

Papalia, Dkk. 2009. Human Developmen (Perkembangan Manusia ) Edisi 10 Buku I. Jakarta : Salemba Humanika.

Slamet Suyanto. (2003). Konsep Dasar Pendidikan Anak Usia Dini. Yogyakarta:UNY.

Soemiarti Patmonodewo. Buku Ajar Pendidikan Prasekolah DepartemenPendidikan dan Kebudayaan Direktorat Jendral Pendidikan TinggiProyek Pendidikan Tenaga Akademik.

Sugiyono.(2007). Metode dan Penelitian Kuantitatif dan Kualitatif. Bandung: Alfabeta.

Sumanto (2006).Pengembangan Kreatifitas Seni Rupa Anak Sekolah Dasar.Departemen Pendidikan Nasional Direktor Jendaral Pendidikan Tinggi,Direktorat Ketenagaan.

Sudijono, Bambang Dkk. 2005 MetodePengembangan Fisik.Jakarta

Suharmin Arikunto, 2010 .Prosedur Penelitian Suatu Pendekatan Praktek .Jakarta Rineka Cipta.

Undang-Undang RI No. 21 Tahun 2003 tentang "Sistem Pendidikan Nasional"

Yamin Martinis, Sanan jamilah Sabri, 2010. Panduan Pendidikan Anak Usia Dini , Jakarta:Gaung Persada 